\title{
EQUiLIBRIUM
}

Quarterly Journal of Economics and Economic Policy

2016 VOLUME 11 ISSUE 4, December

p-ISSN 1689-765X, e-ISSN 2353-3293

www.economic-policy.pl

Sekuła, A., \& Śmiechowicz, J. (2016). Systems of General Grants for Local Governments in Selected EU Countries Against the Background of the General Theory of Fiscal Policy. Equilibrium. Quarterly Journal of Economics and Economic Policy, 11(4), 711-734. DOI: http://dx.doi.org/10.12775/ EQUIL.2016.032

Alicja Sekuła*

Gdańsk University of Technology, Poland

Joanna Śmiechowicz ${ }^{* *}$

Maria Curie-Skłodowska University, Poland

\section{Systems of General Grants for Local Governments in Selected EU Countries Against the Background of the General Theory of Fiscal Policy}

JEL Classification: $H 71 ; H 50 ; H 61 ; H 30$

Keywords: fiscal policy; general grants; European Union; central government expenditures; public finance

\begin{abstract}
Fiscal policy, including its expenditure aspect, is often discussed and analysed from a variety of angles in the literature on public finances, undoubtedly due to the major importance of this topic. However, not all areas of the expenditure part of fiscal policy have been subjected to in-depth analysis. One of the less discussed tools of fiscal policy consists of general purpose transfers, which are a certain type of expenditure passed from the central budget to local governments. This study focuses on presenting the systems for subsidising sub-national governments in selected European countries and evaluating, based on a synthetic measure, the fiscal policies of France, Italy, the Netherlands, Lithuania, Poland and Finland implemented by means of general transfers, with the aim of identifying the
\end{abstract}

(C) Copyright Institute of Economic Research

Date of submission: April 12, 2015; date of acceptance: June 8, 2016

* Contact: alicja.sekula@zie.pg.gda.pl; Gdańsk University of Technology; Faculty of Mana-gement and Economics, Narutowicza 11/12 80-233 Gdańsk

** Contact: joanna.smiechowicz@ poczta.umcs.lublin.pl; Maria Curie-Skłodowska University; Faculty of Economics, M. Curie-Sklodowska 5; 20-031 Lublin 


\section{Alicja Sekuła, Joanna Śmiechowicz}

best fiscal policy with respect to subsidising and the characteristic features determining its success. The method of unitisation of statistical feature values was employed in this study to enable comparative analysis. As suggested by the results of the analysis, spanning the years 2003-2012, the highest-ranked fiscal policy implemented via general-purpose transfers has been developed in the Netherlands.

\section{Introduction}

As one of the types of expenditures financed by the state budget, general grants are a tool of fiscal policy that varies greatly from country to country in terms of the manner and extent of application. This can be explained by the fact that while the European Union regulations are uniform with respect to such fiscal policy tools as budget deficit and public debt, the member states are not restricted by them when it comes to structuring the state's expenditures. What is more, the scope and principles of awarding general grants as one of the sources of funds for local governments in the individual countries result from their independent decisions concerning the preferred extent of decentralisation and division of public revenues between the central and sub-national level. The main aim of this study is to present the subsidising systems and evaluate the fiscal policy implemented via general grants in six selected European Union countries - France, Italy, the Netherlands, Lithuania, Poland and Finland (chosen because of their diverse systems of organisation of state authorities, local governments and public finances) in order to identify the best system and, on this basis, the desirable features of such transfers. In order to capture the effect of any changes to the rules governing the award of general grants and to enable a more comprehensive assessment of fiscal policy in this respect, a ten-year period between 2003 and 2012 was considered in the study. To enable comparative analysis, the method of unitisation of values of specific statistical features was employed. A synthetic indicator was thus obtained to rank the fiscal policy pursued by the individual states via general grants and to identify the best one.

\section{Subsidies for Local Governments in Contemporary Fiscal Policy}

Fiscal policy and monetary policy constitute parts of the state's financial policy, understood to mean conscious and purposeful activities of persons and institutions that include establishing and achieving specific goals via financial means (measures, actions). Its essence is the ability to collect and 
spend public funds to achieve objectives of both social and economic nature (Kosikowski \& Ruśkowski, 2008, p. 33). Nowadays, it is expressed by the economic programmes for future periods, adopted by public authorities (Chojna-Duch, 2010, p. 44). Since fiscal policy is an inherent part of the financial policy followed by the state, it should pursue the same goals, in particular, achievement of a high level of use of the productive capacity, stabilisation of the fluctuations arising from the economic cycle by stimulating and reducing demand in the economy, creation of favourable conditions for making financial savings through optimisation of the tax burden, offsetting excessive inequalities in the division of revenue between members of society, or curbing unemployment and supporting job creation. Specific fiscal policy tools, including taxes and other public charges, expenditures, budget deficits, public debt and the guarantees issued, should contribute to the accomplishment of such objectives (Owsiak, 2002, p. 279). Although specialist publications stress that the primary general purpose of fiscal policy is to provide the state (or public authorities) with nonreturnable financial resources enabling it to fulfil their duties, according to a more frequently expressed view, public expenditure is also a very important instrument of fiscal policy (Ferreiro et al., 2012, p. 652; Owsiak, 2005, pp. 359-361; Palley, 2009, pp. 321-322; Sekuła, 2011, pp. 209-210; Szarowská, 2011, p. 170). Academically, the concept of fiscal policy is usually considered equivalent to budgetary policy. It is a commonly accepted view that it encompasses both budgetary revenues and expenditures (of central and local governments) and non-budgetary ones, and in the area of expenditure it is expressed by the right, from the viewpoint of socioeconomic objectives, choice of directions and the method of their implementation (Pietrzak et al., 2008, p. 290). The literature also quotes studies focusing on the expenditure aspect of fiscal policy and highlights the effect of decisions and actions taken by European Union member states on GDP growth and the unemployment rate. The states pursue their individual, quite freely structured fiscal policies with respect to expenditure, therefore achieving different effects. That is because expenditure is not governed by community regulations, which lay down strict rules as to the budget deficit and public debt (Krčílková \& Antoušková, 2009, pp. 343-348).

General grants, an important source of funds enabling local governments to fulfil their duties, constitute a part of state budget expenditures and as such should be considered a tool of fiscal policy. The size of general-purpose transfers and their share in the general structure of expenditure at the central level or GDP depend on the model of public finances adopted in a particular country and the degree of their decentralisation. In view of the fact that decentralisation is a dynamic process increasing the scope and 
variety of tasks carried out by local governments, it leads to continuous enhancement of the allocation and redistribution functions performed by local finances. This trend is associated with the principles of adequacy and subsidiarity formulated in the European Charter of Local Self-Government, resulting in the necessity of supplementing local government's budgets with funds from the state budget. Establishing the right level and form of this support is becoming an increasingly important issue of state fiscal policy (Guziejewska, 2007, p. 71). On the whole, from the point of view of financial independence, general grants are the preferred type of revenue of local governments as they ensure freedom of choice as to the allocation of expenditures. By contrast, the manner of use of specific grants, an alternative means of supplementing the budgets of local governments from the state budget, is determined by the socio-economic policy pursued by the government and therefore constitutes a more convenient and strictly controlled fiscal policy instrument. An important matter from the point of view of flexibility of transfers from the state budget is how to define the rules of the grant awarding process. The less precise they are, the easier it is to reduce and increase the amount of transfers, treating them as a discretionary tool of fiscal policy (Sekuła, 2009b, p. 756). Funds transferred from the state budget to local governments according to objective and legal criteria, as in the case of general grants, perform a stabilising role in the business cycle. However, in the case of this type of transfer it is still possible to take decisions at the central level, resulting in their significant increase or decrease.

Focusing on general grants as a fiscal policy tool, it should be emphasised that it is an essential source of funds for local governments, making it possible to offset the differences in the revenue-generating potential and reduce the disparities in the spending potential of local government units. Thus, general grants enable the redistribution function, as well as allocation of funds at a higher level. They generally result in an increase of expenditures made by local governments, but they should not have an impact on the trends of spending of their funds.

Although state budget expenditures in the form of general grants constitute an element of fiscal policy and an issue of major importance due to their size and share in the general structure of central level expenditure, they have not been given sufficient attention in Polish or foreign literature. Meanwhile, the problem of utilising general grants as a source of funds to finance local governments' tasks, their share in local authorities' revenues and the consequences of utilising this form of budget revenues has been widely discussed. Similarly, specialist literature devotes much attention to fiscal policy implemented via budget expenditures analysed from a variety of angles. Mainly, however, researchers focus on the changes in the size 
and structure of public expenditures in various phases of the economic cycle (Szarowská, 2011) and demonstrate that some of them fluctuate more strongly over time (Lane, 2002). Other issues generating considerable interest relate to the relationship linking the size and structure of budget expenditures with election cycles (Schuknecht, 2000; Efthyvoulou, 2011). As a fiscal policy tool, budget expenditures, with account taken of their variety and preferred type, are also evaluated with respect to their impact on macroeconomic quantities, such as GDP (Gupta et al., 2005) and unemployment rate (Krčílková \& Antoušková, 2009). Nevertheless, researchers usually focus on the directions of expenditures and support for specific areas of public services. Sometimes only one selected type of budget expenditure is analysed (usually investment expenditure) and evaluated in terms of its impact on economic growth (Ocran, 2009). However, expenditures financed by central budgets in the form of general grants, which are an important element of fiscal policy, do not receive sufficient attention - hence the need to fill this gap and give appropriate importance to the issue of subsidisation in the context of implementation of a state's fiscal policy.

\section{Description of Subsidisation Systems in Italy, Finland, Lithuania, the Netherlands, France and Poland}

Determination of the directions and methods of spending of collected funds is an inherent part of fiscal policy. From the state budget level, some of them are transferred to the regional and local government level. Their size and transfer rules and procedures depend on the political system in a particular country, the degree of decentralisation and the resulting system, tasks and sources of revenue of the local government. It is also formally required that delegation of specific tasks to the sub-national level should be accompanied by appropriate partial decentralisation of public revenues and expenditures. Since this requirement is impossible to meet with respect to all local government units, the state budget supports the sub-national government by means of transfers, following specific rules, differing from country to country.

Italy - one of the founding Member States of the European Union - is among the more highly populated countries in Europe. The territorial division of the country is organised into three tiers. The sub-national government system consists of 15 regions with an ordinary status, 5 regions with a special status, 102 provinces and more than 8000 municipalities. The 
regions enjoy a high degree of autonomy even though Italy is not a federal state.

The basis for financial support of the sub-national government is defined in Article 119 of the Constitution of the Italian Republic, providing for an equalisation fund without restrictions in respect of the allocation of financial resources, for the territories characterised by a lower per-capita taxable capacity. It can therefore be said that the Constitution introduced the principle of balanced development of regions while empowering the state to subsidise the local government units that need support.

In practice, the principle of adequacy was initially not followed with respect to the Ordinary Statute Regions (OSRs). As recently as in the early 1990s, OSRs had virtually no independence, with up to $95 \%$ of their expenditure being financed by central government transfers. Nearly all of these grants were conditional, which means that the central government dictated the terms of use of the resources. Furthermore, the fund spending procedures were highly specific and hedged with multiple restrictions. The resources thus obtained were chiefly spent on the health service. To improve this situation, a number of decisions were taken regarding the regions' revenues, with the aim of increasing their autonomy. As a result, the share of expenditure financed by transfers dropped to $48 \%$. After the reform, the present grant award system employs a more general formula, including analysis of expenditure needs (like in Australia) in addition to calculations based only on the revenue-generating or taxable capacity (like in Canada). The amount transferred to a particular region is the difference between the VAT amount allocated according to the equalisation formula (EVAT) and the VAT amount apportioned to the region based on the estimated consumption by its inhabitants. While there is a certain likeness to the German system in terms of calculation of equalisation transfers, such as using the share in VAT, reference to the fiscal capacity and implementation of horizontal equalisation, the Italian system differs significantly from its German counterpart. In the German system, the purpose of horizontal redistribution is only to equalise the fiscal potential of the constituent states, while the Italian system provides for the needs and costs with respect to health service and the differences in the costs of public service provision. The equalization formula introduced in Italy does not ensure matching a specific level of taxable capacity, so per capita taxable capacity can differ from the mean by more than 10\% (Arachi \& Zanardi, 2004, pp. 327-330).

Another country under discussion is the Republic of Finland. The basic issues concerning the local government system are regulated primarily by Article 121 of the Constitution of Finland. 
In 1960-1980, the period of construction of the Nordic welfare state, municipalities in Finland were assigned a number of new responsibilities. The system of grants as a means of support played a crucial role in the development of the welfare state. Such a system was necessary in order to equalize the municipalities' capacity to introduce new statutory services while maintaining the local taxation at acceptable levels. This was achieved, inter alia, by employing categorical grants, awarded under the supervision of central government bodies, as well as specific standards stipulating the manner of management of the tasks for which the grants were awarded. At the same time, the municipalities' self-sufficiency was restricted by this change despite their extensive formal independence and fiscal autonomy of the sub-national government in terms of revenue. This autonomy was expressed by the municipalities' right to levy a tax on personal income without any limitations in terms of tax rates, personal income tax being the major source of revenue for municipalities, beside grants. Until 1993, more than $90 \%$ of grants were of the specific matching type, aimed in particular at such areas as education, social assistance and healthcare. The types of expenditures qualifying for support were precisely specified by provisions of the law. Not all expenditures were co-financed by the state, even if they were associated with a particular task. Since 1969, the grant rates have been determined according to a multi-criteria capacity classification system, categorising municipalities with respect to their demand for state support. The main classification criterion was the tax base per capita (weight of criterion: 50\%). The other criteria included: net charge for the performance of obligatory tasks, poor financial situation of a municipality, certain unfavourable structural factors, such as a dispersed population, or structural changes, e.g. a high unemployment rate. Based on these criteria, an annual classification of municipalities was prepared. Those in the first class received the highest (in relation to the costs) percentage rate of support, while municipalities that fell into the tenth class were awarded the lowest percentage rate of support. The classification system was completely abolished at the beginning of 1996 to be gradually replaced, starting from 1993, by a system based on general grants and nonmatching sector grants. The reason behind the reform was the wish of municipal authorities to achieve a greater independence and freedom of decision-making. The new system reduced the sector control over municipalities and gave them greater autonomy in the provision of services. At present, general grants consist of three parts, the first of which is based on the population criterion, the second is a supplement calculated on the basis of income tax, and the last is of discretionary nature. The two types of sector grants, i.e. for social assistance/healthcare and education/culture, are of 
non-matching and general nature, although they are officially referred to as sector specific grants (Oulasvirta, 1997, pp. 398-400). At the national level, replacing specific matching grants with general non-matching grants facilitates coordination of the economic policy by the government. Compared with the previous system, the new one makes it easier to reduce the aggregate amount of grants. Wishing to avoid serious political consequences (loss of votes), politicians at the national level are inclined to shift responsibility for unpopular decisions involving expenditure cuts onto the subnational government and local politicians. On the other hand, local governments enjoying autonomy at the time of recession have the power to make their own decisions concerning the expenditure cuts required by the central government (Oulasvirta, 1997, pp. 412-413).

Figure 1. Sources of municipal budget revenues of the Republic of Lithuania

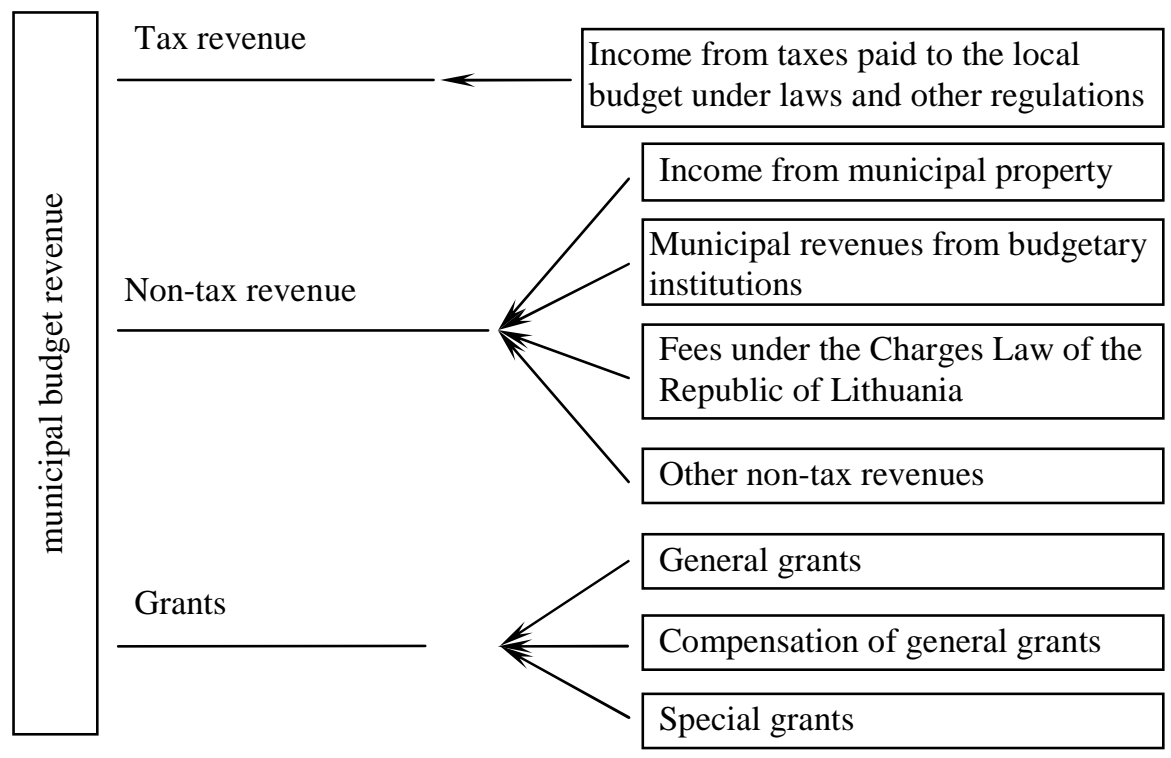

Source: Ginevičius et al. (2014, p. 183).

Another country, the Republic of Lithuania, has a relatively new subnational government system, created after 1990. The Lithuanian selfgovernment was developed with the objective of supporting and boosting the independence of municipalities by increasing their competences. Putting this idea into practice has given rise to problems with funding. These issues are particularly complicated because of the strongly diversified po- 
tential of Lithuanian municipalities, leading to unequal opportunities to generate revenues and capacities of providing services to the population. These problems are partly solved by revenue transfer from the state budget in the form of grants. Due to the fact that the transfer takes place between public authorities' budgets, it is also known as the interbudgetary redistribution of funds.

The act on the sources of revenues of municipality budgets in Lithuania provides for three sources of revenues: tax revenues, non-tax revenues and grants from the state budget (Fig. 1). The first two are classified as own revenues, whereas the last type constitutes state support for performance of the municipality's tasks, with the proviso that any unused funds must be returned to the state budget at the end of the year. In terms of quantity, budgets of the Lithuanian municipalities consist mainly of tax revenues and grants from the state budget. In 2009-2013 the latter accounted for ca. $50-60 \%$ of revenues of municipality budgets.

The Lithuanian law provides that general grants from the state budget should be allocated to the following purposes:

- reducing disparities between actual and planned personal income tax receipts; the recipients are municipalities with lower actual tax receipts per capita in the previous month (relative to the average for all units);

- reducing disparities in the structure of expenditures that arise from objective (demographic, social, etc.) factors, beyond the control of local authorities.

General grants are awarded for:

- implementation of tasks assigned;

- education of children, young people and adults;

- implementation of programmes adopted by the parliament and central government.

Equalisation grants are transferred to the budgets of municipalities to compensate for the changes in their revenues and expenditures resulting from the decisions of the government and parliament (Ginevičius et al., 2014, p. 184).

The increase in inequalities between municipal revenues observed in recent years calls for a better redistribution of revenue, because it is thought that the existing system of local government funding does not provide a solution to this problem.

The next country presented here, the Netherlands, is a constitutional monarchy. In respect of the position of sub-national government and its financial system in the structure of the state, the local government system in the Netherlands is characterised by a small proportion of own revenues in overall revenue, and a heavy dependence of local authorities on central 
budget transfers. The main sources of funds for the Dutch municipalities are general and specific grants from the state budget. They jointly account for nearly 5.6\% of GDP (2009), of which general grants constitute 3.1\%, specific grants $2.3 \%$, and local taxes only $0.8 \%$. The Dutch provinces also rely heavily on general and specific grants, accounting for ca. $0.25 \%$ and $0.4 \%$ of GDP, respectively. These data refer to the national average. In some provinces, revenue from property is of primary importance, arising from ownership rights to energy companies (Bos, 2012, p. 14).

General grants are transferred to municipalities and provinces via the municipal fund and provincial fund, respectively. Their size depends on the changes in expenditure from the state budget, which means that the municipalities and provinces jointly participate in budget cuts or additional expenditure. For example, $€ 1$ billion of additional state budget expenditure translates into a global increase in the revenue of municipalities and provinces by ca. $€ 200$ million. A sample structure of municipalities' revenues is presented in Table 1.

Table 1. Size and composition of the revenue of Dutch municipalities in 2009

\begin{tabular}{lcccc}
\hline \multicolumn{1}{c}{ Type of revenue } & $\boldsymbol{€}$ billion & $\boldsymbol{\%}$ & $\boldsymbol{\%}$ GDP & $\begin{array}{c}\boldsymbol{€} \text { thousand/ } \\
\text { inhabitant }\end{array}$ \\
\hline Transfer from municipality fund & 17.7 & 37 & 3.1 & 1.1 \\
\hline Specific transfers by central govern- & & & & \\
ment, including: & 12.9 & 27 & 2.3 & 0.8 \\
$\quad$ - Social assistance, & 9.4 & 20 & 1.6 & 0.6 \\
$\quad$ - Other. & 3.5 & 7 & 0.6 & 0.2 \\
\hline Sale of goods and services & 11.3 & 23 & 2.0 & 0.7 \\
\hline Taxes & 4.4 & 9 & 0.8 & 0.3 \\
\hline Property income & 1.9 & 4 & 0.3 & 0.1 \\
\hline Total revenue & 48.1 & 100 & 8.4 & 2.9 \\
\hline
\end{tabular}

Source: Bos (2012, p. 43).

Grants from the municipal fund are calculated for the individual municipalities using a complicated formula, including a number of objective criteria. The aspects taken into consideration include the size of population, taxable capacity, as well as external factors, such as the role in the region or the social and material structure of the population. The indicators used in calculation of a grant are determined on the basis of formulae including, in particular, the number of households drawing welfare benefits, the size of ethnic minority populations, the number of young and elderly persons, population density and the area of the historical centre of the municipality. The grant calculated from such a formula is increased by a fixed amount for the Frisian Islands and the country's four main cities. The average general 
grant was ca. $€ 1000$ per capita and between $€ 600,000$ and $€ 2,500,000$ for the individual units. In practice, large municipalities receive higher per capita grants than smaller units. This is due to greater demand for social services: as demonstrated by studies, cities tend to attract lower-income persons. Equally complex formulae are used in the case of the provincial fund and specific grants (Bos, 2012, pp. 43-44).

The French Republic, in common with the Italian Republic, is one of the founding Member States of the European Union. In both these countries public task funding was initially highly centralised; its decentralisation was achieved in the course of reforms. At present, transfers from the state budget are an important and increasingly significant part of the revenue of local government units in France. In the past they used to consist largely of specific grants, but today they are subventions that can be freely disposed of by local authorities (Śmiechowicz, 2008, pp. 421-422). Sub-national government revenues are mainly composed of tax revenues $(50 \%$ of the entire funds) and transfers from the state budget (35\%). The latter are awarded for different purposes and take on different forms. The functioning of the system is additionally complicated by the fact that the individual grants are not allocated for single, specific aims. This complexity makes it difficult to analyse the whole system. The three main targets for state budget transfers are:

- Financing of tasks assigned to local governments. Whenever the central government sets a task for a local government unit, it also allocates funds for its implementation - from tax revenue or in the form of grants. Since public tasks assigned to the sub-national government are usually financed by transfers from the state budget rather than from tax resources, the proportion of central budget transfers in overall revenues shows an increasing trend (Jamet, 2007, p. 22). Moreover, the amount of grant is calculated from a formula at a rate more favourable than the inflation rate.

- Compensation for tax exemptions. If the central government decides to exempt a certain group of taxpayers from a specific local tax or to reduce the tax rate, it compensates the local government for the lost revenue. Most of these exemptions apply to property tax and business tax paid annually by natural and legal persons carrying on economic activity.

- Equalisation. The state uses transfers to reduce the disparities between local governments in their "purchasing power" defined as the expenditure to revenue ratio. The amount of equalisation to be distributed between the individual local governments is determined every year by the 
central government based on the indicators of their respective revenues and expenditures.

In the original system, the individual grants were linked to their specific purposes. Over time, however, when it became increasingly difficult to compensate exactly for various shifts and exemptions by means of transfers, the individual grants were combined into larger ones. The present system, which has resulted from these changes, is of an intermediate nature. It consists primarily of the general grant, referred to by the acronym DGF (Fr. dotation globale de fonctionnement), but individual types of grants still exist as well. DGF accounts for more than $60 \%$ of funding from the state budget and includes the transfer for all the three target areas. Local governments are entitled to use it at their own discretion. One part of the grant constitutes an amount proportional to the amounts paid the year before, depending on the size of the population and also including compensation for the elimination of the pay-related portion of the business tax in 1999. The other part is intended to promote equalisation; it depends on the deficiency of taxable capacity and tax revenue from households. It includes the urban equalisation grant, rural equalisation grant and state equalisation grant.

There are other grants beside DGF, financing the individual expenditures, e.g. the decentralisation grant - DGD (Fr. dotation globale de décentralisation). Financed by the central government, it has the form of a lumpsum grant. The principle of awarding DGD is that the amount of transfer should cover all additional costs incurred as a result of decentralisation of tasks, which are delegated to the regional-level governments. For example, in 2004 DGD accounted for $20 \%$ of the revenues of regions (Josselin et al., 2013, p. 325).

The sub-national government in Poland, the last country considered here, was formed roughly in the same period as the Lithuanian system: its 25 th anniversary was celebrated in 2015.

The obligatory sources of local government revenues are referred to in various Polish laws, including the most important one - the Polish Constitution. According to the division presented therein (Article 167), there are three types of local government sources of revenue: own revenues, general grants (termed general subsidies in the constitution) and specific grants from the state budget. The three different groups of revenues were designated with respect to the control of receipts and spending of funds obtained from a particular source: the extent of control is the greatest for own revenues and the smallest for specific grants. The significance of general grants is varied in the local governments budgets: the lowest in provinces (ca. 
$16 \%$ of budget revenues) and the highest in land counties, where they account for ca. $43-45 \%$ of revenues.

Under the Polish law, own revenues include receipts from shares in personal income tax (PIT) and corporate income tax (CIT), which constitute a part of the state budget revenues. This inclusion is of formal nature only, because such receipts do not have the characteristic feature attributed to own revenues, i.e. fiscal autonomy, which relates to the scope of powers to establish and control the revenues that enable a unit to manage its finances independently; in terms of autonomy, they bear the most resemblance to general grants.

The primary aim of fund transfer in the form of general grants is to supplement a particular unit's own revenues. What distinguishes them from specific grants is the freedom as to the way of fund disposal - the decision concerning the allocation of funds from general grants rests with the legislative body.

As of 2004, general grants consist of three components:

- equalisation,

- balancing (regional in provinces),

- educational.

The first and the third component, i.e. equalisation and educational, are transferred from the state budget. The second one derives from payments from wealthier units and constitutes an element of horizontal equalisation of revenues.

The first component is referred to as an equalisation general grant. Its purpose is to offset the difference of revenues earned by local government units at a particular tier and to assist economically weaker units. Another component - the balancing general grant (regional in provinces) - consists of payments made by units characterised by a high fiscal capacity. Because of the method of collection and division (transfers from wealthy units to poor ones), it is commonly referred to as a 'Robin Hood charge' (Polish: janosikowe). This type of general grant is highly controversial, not only in Poland, due to its functioning in the local government finance system and method of calculation of wealthy units' payments. Objections to the compulsory contributions to the Robin Hood charge were also raised, for example, by the German state of Hesse.

The last component of the general grant is the educational general grant. In terms of the amount, it is the largest part of the general grant, especially in counties and communes. Its overall amount for all the local government units is specified by the budget act. In the case of the educational component the idea behind the solution is dubious, i.e. financing of education by means of grants. The essence of general grants is to minimise dispropor- 
tions or supplement funds, rather than finance local government units' functions. Formally, it is not appropriate to link the educational general grant revenues with expenditure on education due to the features of the general grant (unspecified purpose of expenditure). This is the case in practical terms, however, due to the considerable share of education expenditure in overall spending. To emphasise this relationship, the term 'educationspecific grant' is often used. Hence, subsidising expenditure on education is considered contrary to the general idea of general grants, but rationally justified.

In practice, therefore (Sekuła, 2009a, p. 109):

- the equalisation general grant constitutes a means of vertical division of funds between local government and the state,

- the balancing/regional general grant is a tool of horizontal redistribution between units of the same tier,

- the education general grant is an instrument for financing education functions.

\section{Research Methodology}

In order to investigate the general grants awarded to local governments as part of the fiscal policy pursued by the state, the authors analysed the expenditure on general grants in six selected EU countries - Italy, Finland, the Netherlands, Lithuania, France and Poland - having diverse systems of organisation of central and sub-national government, different principles of division of public revenue between the central and local governments and diverse socio-economic policies and, consequently, different scopes of public expenditures.

The fiscal policy and its effects are of long-term character. Therefore, the analyses performed as part of this study cover the data for a relatively long period of ten years between 2003 and 2012. Focusing on this period, it is possible to identify the financial effects, expressed by the size of expenditure on general grants from central budgets, of the changes introduced to the principles of subsidising local government units by the public authorities in the countries investigated.

The research was based on the data collected by Eurostat - the statistical office of the European Union - and, because of the absence of certain information relating to Poland, on Sprawozdania $z$ wykonania budzetu państwa (Reports on state budget implementation) for 2003-2012. To examine the fiscal relationships between the national and sub-national government sectors in the individual states, the authors used the value of ex- 
penditures in the form of general grants transferred from the central government to local governments. Such expenditures were determined on the expenditures basis of Classification of the functions of government, COFOG, which classifies expenditures according to a system of divisions (functions), groups and classes. The expenditures under discussion are recorded in the General public services division as a group titled Transfers of a general character between different levels of government. The COFOG classification is based on the historical European System of Accounts - ESA 95. For this reason, and in order to take advantage of the more comprehensive range of data concerning other quantities used in the study, i.e. the revenues and expenditures at the central level and the revenues of local governments in the countries analysed, the Eurostat data were used, collected according to the ESA 95 methodology. The quantities describing the populations of the individual countries were also obtained from Eurostat. Because of the political system of the countries investigated and the financing policies with respect to the size of general grants, this study uses Eurostat statistical data that apply to the local government level. Since the aforementioned statistics do not specify the size of general grants to the local governments in Poland, the missing data required for analysis were obtained based on Sprawozdania z wykonania budżetu państwa (Reports on state budget implementation) and converted into EUR using weighted average EUR exchange rates for the respective years.

Structuring budget expenditures is one of the aspects of fiscal policy. As previously mentioned, these expenditures include the amounts transferred from the state budget in the form of grants for local governments. In order to evaluate the fiscal policy pursued by the aforementioned countries with respect to the structure of expenditure for grants, the authors employed the method of unitisation of values of the statistical features included in the study to enable further comparative analysis, also known as the zeroed unitarisation method. The normalisation procedure transforms the data to enable calculation of a synthetic indicator, which is the arithmetic mean of all variables, assuming values between 0 and 1 after conversion. It is performed for each feature separately, in a slightly different manner for positively and negatively correlated explanatory variables, in accordance with the following formula (Kukuła, 2012, p. 8; Jezierska-Thole \& Gwiazdzinska-Goraj, 2013, pp. 548-549; Sekuła, 2010, p. 427; Łyszczarz, 2016, p. 174-175): 


$$
z_{s}=\frac{x-\min x}{\max x-\min x} \quad z_{d}=\frac{\max x-x}{\max x-\min x}
$$

where:

$\mathrm{z}$ - normalised variable,

$\mathrm{s}, \mathrm{d}$ - positively and negatively correlated explanatory variables, respectively,

$\mathrm{x}$ - value of the analysed feature for a particular country,

$\max x, \min x-$ maximum and minimum values of variable $\mathrm{x}$.

Five variables were used in this study:

$\mathrm{x}_{1}$ - size of transfers of a general character from the state budget to local governments ( $€$ million/resident) - positively correlated explanatory variable;

$\mathrm{x}_{2}-$ size of transfers of a general character from the state budget to local governments relative to state budget expenditure (\%) - positively correlated explanatory variable,

$\mathrm{x}_{3}-$ size of transfers of a general character from the state budget to local governments relative to state budget revenue $(\%)$ - positively correlated explanatory variable;

$\mathrm{x}_{4}$ - size of transfers of a general character from the state budget to local governments relative to overall revenues of local governments $(\%)$ - negatively correlated explanatory variable

$\mathrm{x}_{5}$ - size of transfers of a general character from the state budget to local governments relative to local governments' property income (\%) - negatively correlated explanatory variable.

Due to the absence of publications focused on analysis of the issue under discussion using the above-described methods, it can be assumed that there is no reliable pattern for dividing the weights between the particular variables. It was decided not to apply the method of Delphi experts (Wierzbicka, 2014, p. 248), permissible in this situation, due to the unavailability of an adequate number of specialists who could assign weights to the variables. Therefore, it should be stated that this study did not apply weights assigned to the individual variables, which means that the weight of each variable is the same and equals 0.2 .

The adopted model of positively and negatively correlated variables fits into the following scheme: it was assumed that the right solution is a high amount of general grants. The greater general purpose transfers in absolute terms ( $€$ per capita) and relative terms (in relation to the state budget), the greater their importance as a tool of fiscal policy. Hence, variables $\mathrm{x}_{1}-\mathrm{x}_{3}$ are positively correlated. On the other hand, general grants should not replace own revenues - their share in the revenues of local governments should be 
of supplementary character, with own revenues having the greatest possible significance. Therefore, variables $\mathrm{x}_{4}$ and $\mathrm{x}_{5}$ are negatively correlated.

The choice of variables reflected the purpose of the study (expenditure on general grants as part of the state fiscal policy) and the availability of data on the Eurostat website.

\section{Size and Importance of State Budget Expenditure on General Grants for Local Governments in Selected EU Countries}

In order to normalise quantitative features, they first need to be collected and summarised. The data for variables $\mathrm{x}_{1}-\mathrm{x}_{5}$ are presented in Tables 2-6.

The size of transfers from the central budget to local governments varied greatly between the countries analysed (Fig. 2). This is not surprising in view of the diverse capacity of public finances, influenced by a number of factors (area of the country, population size, GDP generated). Interestingly, however, the size of general grants changed in a variety of ways in the individual countries over the period investigated.

Figure 2. General grant amount in 2003-2012 in € million

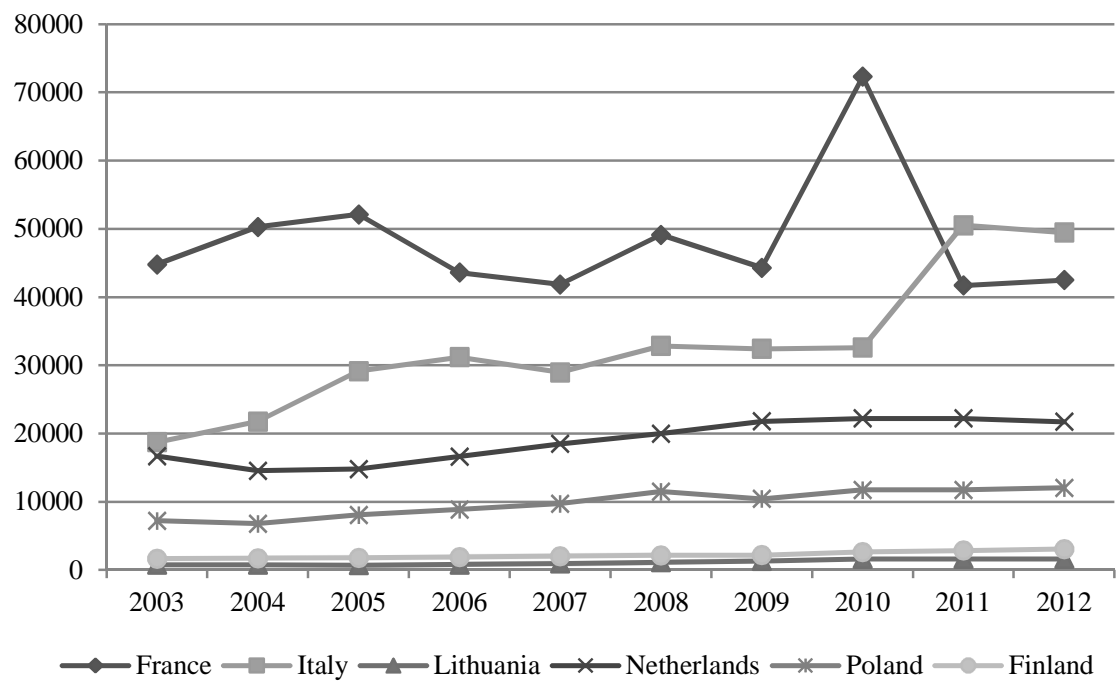

Source: own calculations based on Eurostat, Ministry of Finance data. 
Table 2. Transfers of a general character from the central government budget to local governments in selected EU countries in 2003-2012 (€ per capita)

\begin{tabular}{crrrrrrrrrrr}
\hline Country & $\mathbf{2 0 0 3}$ & $\mathbf{2 0 0 4}$ & $\mathbf{2 0 0 5}$ & $\mathbf{2 0 0 6}$ & $\mathbf{2 0 0 7}$ & $\mathbf{2 0 0 8}$ & $\mathbf{2 0 0 9}$ & $\mathbf{2 0 1 0}$ & $\mathbf{2 0 1 1}$ & $\mathbf{2 0 1 2}$ & mean \\
\hline France & 724 & 807 & 830 & 689 & 658 & 767 & 688 & 1118 & 642 & 651 & 757 \\
\hline Italy & 328 & 378 & 503 & 537 & 497 & 560 & 549 & 551 & 851 & 833 & 559 \\
\hline Lithuania & 222 & 228 & 213 & 243 & 294 & 357 & 410 & 521 & 533 & 538 & 356 \\
\hline Netherlands & 1030 & 894 & 907 & 1017 & 1130 & 1218 & 1322 & 1339 & 1333 & 1298 & 1149 \\
\hline Poland & 189 & 178 & 211 & 232 & 255 & 302 & 273 & 308 & 305 & 312 & 256 \\
\hline Finland & 320 & 331 & 342 & 364 & 385 & 402 & 411 & 494 & 529 & 564 & 414 \\
\hline
\end{tabular}

Source: own calculations based on Eurostat. Retrieved form http://ec.europa.eu/eurostat/ data/database.

The general trend shows an increase in this type of expenditure in the central budgets in the majority of the countries, most significant in the Netherlands. However, it can be observed that in one of the countries - France - the size of general grants at the end of the period analysed was lower than in 2003, although France is the country with the highest expenditure on local government financing in the form of general grants. It is worth emphasising that the size of fund transfers varied significantly in that country from year to year and accounted for a smaller share of overall central budget expenditure than in e.g. Lithuania, Poland, the Netherlands or Italy (Table 3).

Table 3. Transfers of a general character to local governments in relation to state budget expenditure in selected EU countries in 2003-2012 (\%)

\begin{tabular}{crrrrrrrrrrr}
\hline Country & $\mathbf{2 0 0 3}$ & $\mathbf{2 0 0 4}$ & $\mathbf{2 0 0 5}$ & $\mathbf{2 0 0 6}$ & $\mathbf{2 0 0 7}$ & $\mathbf{2 0 0 8}$ & $\mathbf{2 0 0 9}$ & $\mathbf{2 0 1 0}$ & $\mathbf{2 0 1 1}$ & $\mathbf{2 0 1 2}$ & mean \\
\hline France & 11.98 & 12.84 & 12.99 & 11.03 & 10.19 & 11.53 & 10.20 & 15.30 & 9.36 & 9.38 & 11.48 \\
\hline Italy & 5.22 & 5.92 & 7.61 & 7.67 & 6.97 & 7.76 & 7.07 & 7.24 & 11.39 & 11.04 & 7.79 \\
\hline Lithuania & 22.09 & 20.25 & 16.51 & 15.98 & 15.85 & 16.17 & 19.33 & 23.52 & 22.52 & 22.99 & 19.52 \\
\hline Netherlands & 12.56 & 11.00 & 10.93 & 11.67 & 12.10 & 12.37 & 12.40 & 12.03 & 12.78 & 12.52 & 12.04 \\
\hline Poland & 14.12 & 13.50 & 13.50 & 13.07 & 12.79 & 12.67 & 13.37 & 12.43 & 12.70 & 13.34 & 13.15 \\
\hline Finland & 4.43 & 4.40 & 4.42 & 4.63 & 4.79 & 4.69 & 4.53 & 5.20 & 5.47 & 5.65 & 4.82 \\
\hline
\end{tabular}

Source: own calculations based on Eurostat. Retrieved form http://ec.europa.eu/eurostat/ data/database.

Meanwhile, the importance of the general grant as a type of expenditure financed by the central budget increased markedly in Italy, where general purpose transfers from the state budget to local governments accounted for a mere 5\% of the overall expenditure in 2003 to increase more than twofold ten years later (Table 3). By comparison, Finland maintained a stable expenditure policy in that period. While the proportion of expenditures in the 
form of general grants increased by more than 1 percentage point in the period examined, in 2012 they still accounted for less than $6 \%$ of the central budget expenditure and were the lowest both in absolute terms and as a share in the central budget expenditure among all the countries analysed. General grants were the heaviest burden for the central budget of Lithuania (accounting for 23\% of the expenditure in 2010), although in absolute terms they were the lowest among the countries investigated. At the same time, the data contained in Table 4 suggest that general grants absorbed a far greater proportion of state budget revenues than similar transfers in other countries investigated; this proportion was the lowest in Finland, where such grants accounted for only a small share of central budget expenditure.

Table 4. Transfers of a general character to local governments in relation to state budget revenue in selected EU countries in 2003-2012 (\%)

\begin{tabular}{crrrrrrrrrrr}
\hline Country & $\mathbf{2 0 0 3}$ & $\mathbf{2 0 0 4}$ & $\mathbf{2 0 0 5}$ & $\mathbf{2 0 0 6}$ & $\mathbf{2 0 0 7}$ & $\mathbf{2 0 0 8}$ & $\mathbf{2 0 0 9}$ & $\mathbf{2 0 1 0}$ & $\mathbf{2 0 1 1}$ & $\mathbf{2 0 1 2}$ & mean \\
\hline France & 14.34 & 14.58 & 14.77 & 12.33 & 11.56 & 13.75 & 14.10 & 19.99 & 11.71 & 11.47 & 13.86 \\
\hline Italy & 5.87 & 6.68 & 8.93 & 8.55 & 7.53 & 8.58 & 8.40 & 8.47 & 13.07 & 12.40 & 8.85 \\
\hline Lithuania & 24.10 & 22.79 & 17.38 & 16.60 & 16.35 & 17.85 & 24.97 & 28.92 & 26.18 & 24.55 & 21.97 \\
\hline Netherlands & 13.99 & 11.75 & 10.91 & 11.31 & 11.89 & 12.17 & 13.98 & 13.75 & 14.11 & 14.01 & 12.79 \\
\hline Poland & 17.80 & 17.13 & 16.26 & 15.62 & 14.59 & 15.02 & 17.10 & 16.32 & 15.30 & 15.91 & 16.10 \\
\hline Finland & 4.42 & 4.41 & 4.41 & 4.66 & 4.60 & 4.59 & 5.46 & 6.48 & 6.23 & 6.54 & 5.18 \\
\hline
\end{tabular}

Source: own calculations based on Eurostat. Retrieved form http://ec.europa.eu/eurostat/ data/database.

By analysing the size of general grants per resident and their share in the revenues of sub-national governments, it is possible to evaluate this type of local government revenue as the source of financing of its tasks. As indicated by the data in Tables 2 and 3, the Dutch local governments received the most funds per resident - these amounts were more than four times as high as in Poland, where the amount of general grants per capita was the lowest, despite increasing steadily. The size of this type of transfer was quite similar in Lithuania and Finland. Far greater values were observed in France and Italy. What is worth mentioning, the extreme values - the highest for the Netherlands and the lowest for Poland - were widely different from the arithmetic mean of nearly $€ 700$ per capita in 2012 .

Analysis of the data presented in Table 5 also shows the sharp contrasts in terms of the importance of general grants as a source of revenues of local governments in France, Italy, Lithuania, the Netherlands, Poland and Finland. In Lithuania such grants played a key role in the financing of local 
government units, ranging between $39 \%$ and 53\% of their revenues, whereas in Finland it was just a supplementary source of funds of almost marginal importance, accounting for 6-7\% of local government revenue. However, in most of the countries under consideration, general grants are an important, but not principal, means of meeting the expenditures incurred by the sub-national level of government. Any changes in the calculation procedures resulting in an increase or reduction of the amounts transferred from the state budget are directly reflected in the scope of the financed local governments' expenditures.

Table 5. Transfers of a general character to local governments in relation to local governments' revenues in selected EU countries in 2003-2012 (\%)

\begin{tabular}{crrrrrrrrrrr}
\hline Country & $\mathbf{2 0 0 3}$ & $\mathbf{2 0 0 4}$ & $\mathbf{2 0 0 5}$ & $\mathbf{2 0 0 6}$ & $\mathbf{2 0 0 7}$ & $\mathbf{2 0 0 8}$ & $\mathbf{2 0 0 9}$ & $\mathbf{2 0 1 0}$ & $\mathbf{2 0 1 1}$ & $\mathbf{2 0 1 2}$ & mean \\
\hline France & 27.36 & 28.70 & 28.30 & 22.34 & 20.39 & 23.06 & 19.71 & 31.69 & 17.77 & 17.70 & 23.70 \\
\hline Italy & 9.67 & 10.78 & 13.91 & 14.47 & 12.62 & 13.89 & 13.09 & 13.59 & 21.44 & 20.83 & 14.43 \\
\hline Lithuania & 51.56 & 47.26 & 42.39 & 41.14 & 41.71 & 39.02 & 47.31 & 52.19 & 54.16 & 53.36 & 47.01 \\
\hline Netherlands & 21.23 & 18.49 & 18.45 & 20.19 & 21.22 & 21.93 & 22.54 & 23.06 & 23.10 & 22.77 & 21.30 \\
\hline Poland & 29.89 & 25.64 & 25.26 & 24.27 & 23.33 & 22.70 & 24.50 & 23.93 & 23.68 & 24.27 & 24.75 \\
\hline Finland & 6.18 & 6.11 & 6.02 & 6.00 & 5.93 & 5.73 & 5.75 & 6.58 & 6.80 & 7.13 & 6.22 \\
\hline
\end{tabular}

Source: own calculations based on Eurostat. Retrieved form http://ec.europa.eu/eurostat/ data/database.

Table 6. Transfers of a general character to local governments in relation to local governments' property income in selected EU countries in 2003-2012 (\%)

\begin{tabular}{cccccccccccc}
\hline Country & $\mathbf{2 0 0 3}$ & $\mathbf{2 0 0 4}$ & $\mathbf{2 0 0 5}$ & $\mathbf{2 0 0 6}$ & $\mathbf{2 0 0 7}$ & $\mathbf{2 0 0 8}$ & $\mathbf{2 0 0 9}$ & $\mathbf{2 0 1 0}$ & $\mathbf{2 0 1 1}$ & $\mathbf{2 0 1 2}$ & mean \\
\hline France & 2344 & 2606 & 2536 & 1976 & 1843 & 2022 & 1664 & 2820 & 1559 & 1574 & 2094 \\
\hline Italy & 660 & 716 & 918 & 845 & 745 & 778 & 813 & 954 & 1245 & 1308 & 898 \\
\hline Lithuania & 3455 & 2932 & 2187 & 2173 & 2174 & 2751 & 5025 & 5722 & 5647 & 5001 & 3707 \\
\hline Netherlands & 573 & 487 & 520 & 514 & 518 & 550 & 682 & 806 & 793 & 772 & 621 \\
\hline Poland & 1461 & 1248 & 1118 & 576 & 531 & 595 & 798 & 1798 & 1603 & 1640 & 1137 \\
\hline Finland & 203 & 192 & 192 & 198 & 174 & 169 & 187 & 240 & 245 & 258 & 206 \\
\hline
\end{tabular}

Source: own calculations based on Eurostat. Retrieved from http://ec.europa.eu/eurostat/ data/database.

The data contained in Tables 2-6 were normalised using the formula presented in the section devoted to methodology. The results of this procedure are shown in Table 7.

Basing on the selected methodology and the variables used in the study, with respect to fiscal policy carried out by means of general grants for the local government, the Dutch system was given the highest rating. As re- 
gards one of the variables - the size of transfers per capita - the values were the highest among the countries under discussion. In the case of two other variables, expressing the share of general grants in the revenues and expenditures of the state budget (a measure eliminating the effect of the country's wealth on the size of general grants), Lithuania was a clear leader. The figures for the Netherlands were average in this respect.

Table 7. Normalised values of measures included in the study

\begin{tabular}{ccccccc}
\hline variable & $\mathbf{x}_{\mathbf{1}}$ & $\mathbf{x}_{\mathbf{2}}$ & $\mathbf{x}_{\mathbf{3}}$ & $\mathbf{x}_{\mathbf{4}}$ & $\mathbf{x}_{\mathbf{5}}$ & mean \\
\hline France & 0.56 & 0.45 & 0.52 & 0.57 & 0.46 & 0.512 \\
\hline Italy & 0.34 & 0.20 & 0.22 & 0.80 & 0.80 & 0.472 \\
\hline Lithuania & 0.11 & 1.0 & 1.0 & 0.0 & 0.0 & 0.422 \\
\hline Netherlands & 1.0 & 0.49 & 0.45 & 0.63 & 0.88 & 0.690 \\
\hline Poland & 0.0 & 0.57 & 0.65 & 0.55 & 0.73 & 0.500 \\
\hline Finland & 0.18 & 0.0 & 0.0 & 1.0 & 1.0 & 0.436 \\
\hline
\end{tabular}

Source: own calculations.

The next two variables are negatively correlated explanatory variables. It was assumed that the right solution involves high general grant amounts, hence $\mathrm{x}_{1}-\mathrm{x}_{3}$ as positively correlated explanatory variables; on the other hand, general grants are not meant to replace own revenues, so their share in the revenues of local governments should be of supplementary character, with the greatest emphasis on own revenues characterised by extensive fiscal autonomy, represented here by property income. In the case of two variables $\left(\mathrm{x}_{4}\right.$ and $\left.\mathrm{x}_{5}\right)$ Finland is an undisputed leader, although the Netherlands, despite the common opinion concerning low receipts from own revenues, is ranked only worse than Italy but better than e.g. France.

The low rank of Finland, a country whose local governments enjoy considerable independence and a wide range of own revenues, is due to the fact that the receipts from own revenues cannot be considered an instrument of fiscal policy since they do not pass through the state budget.

With the lowest amount of general grants per capita, Poland was third in the final ranking - behind the Netherlands and France.

\section{Conclusions}

This study, devoted to the topic of general grants as a tool of fiscal policy, fills a gap in the literature on public finances. The results of the analysis conducted indicate that although the size and scope of general grants are 
very different in the individual countries in absolute terms, in per capita values and expressed as a proportion of the central budget and local government revenues, this means of support was an important instrument of fiscal policy in all the countries analysed, i.e. France, Italy, the Netherlands, Lithuania, Poland and Finland, accounting for between nearly 5\% and nearly $20 \%$ of the central budget expenditure. Simultaneously, using the method of unitisation of the statistical features included in the study, a comparative analysis of fiscal policy conducted via general grants was performed to create a ranking of countries, where the policy of the Netherlands was ranked the best and that of Lithuania the worst. By applying the aforementioned method it is possible to formulate recommendations concerning the structure of general grants based on the model of the country that received the highest ranking. The results obtained may contribute to further, extended studies of the fiscal policy implemented in the form of general grants with respect to both territory and the range of variables included in the analysis.

\section{References}

Arachi, G., \& Zanardi A. (2004). Designing Intergovernmental Fiscal Relations: Some Insights from the Recent Italian Reform. Fiscal Studies, 25(3). DOI: http://dx.doi.org/10.1111/j.1475-5890.2004.tb00542.x.

Bos, F. (2012). Economic Theory and Four Centuries of Fiscal Decentralisation in the Netherlands. OECD Journal on Budgeting, 2. DOI: http://dx.doi.org/ 10.1787/budget-12-5k8zpd5cczd8.

Chojna-Duch, E. (2010). Podstawy finansów publicznych i prawa finansowego. Warsaw: LexisNexis.

Efthyvoulou, G. (2011). Political Budget Cycles in the European Union and the Impact of Political Pressures. Public Choice, 153(3-4). DOI: http://dx.doi.org/ 10.1007/s11127-011-9795-x.

Ferreiro, J., Garcia del Valle, M., \& Gomez, C. (2012). Similarities and Differences in the Composition of Public Expenditures in the European Union. Journal of Economic Issues, 46(3). DOI: http://dx.doi.org/10.2753/JEI00213624460303.

Ginevičius, R., Slavinskaitè, N., \& Gedvilaite, D. (2014). Regional Differentiation of Revenues Collected by Local Governments of Lithuania. Business, Management and Education, 12(2). DOI: http://dx.doi.org/10.3846/bme.2014.245.

Gupta, S., Clements, B., Baldaci, E., \& Mulas-Granados, C. (2005). Fiscal Policy, Expenditure Composition, and Growth in Low-income Countries. Journal of International Money and Finance, 24(3). DOI: http://dx.doi.org/10.1016/ j.jimonfin.2005.01.004.

Guziejewska, B. (2007). Subwencje i dotacje dla samorządu terytorialnego w polityce finansowej państwa. Gospodarka Narodowa, 4. 
Jamet, S. (2007). Meeting the Challenges of Decentralisation in France. $O E C D$ Papers, 31. DOI: $10.1787 / 127050885680$.

Jezierska-Thole, A., \& Gwiazdzinska-Goraj, M., (2013). Assessment of the Level of Economic Development of Rural Areas of Northern Poland. Rural Development, 6 .

Josselin, J.-M., Padovano, F., \& Rocaboy, Y. (2013). Grant Legislation vs. Political Factors as Determinants of Soft Budget Spending Behaviors. Comparison Between Italian and French Regions. European Journal of Comparative Economics, 10(3).

Kosikowski, C., \& Ruśkowski, E. (Ed.) (2008). Finanse publiczne i prawo finansowe. Warsaw: Oficyna a Wolters Kluwer business.

Krčílková, M., \& Antoušková M. (2009). Can Fiscal Policy Be a Common Underlying Factor Influencing GDP Growth and Unemployment in the EU? In P. Jedlička (Ed.). Ekonomický rozvoj a management regionu. Hradec Králové: Gaudeamus.

Kukuła, K., (2012). Propozycja budowy rankingu obiektów z wykorzystaniem cech ilościowych oraz jakościowych. Metody Ilościowe $w$ Badaniach Ekonomicznych, 13(1).

Lane, Ph. (2002). The Cyclical Behaviour of Fiscal Policy: Evidence From the OECD. Journal of Public Economics, 87(12). DOI: http://dx.doi.org/10.1016/ S0047-2727(02)00075-0.

Łyszczarz, B. (2016). Public-private Mix and Performance of Health Care Systems in CEE and CIS Countries. Oeconomia Copernicana, 7(2), 169-185. DOI: http://dx.doi.org/10. 12775/OeC.2016.011.

Ocran, M. (2009). Fiscal Policy and Economic Growth in South Africa. Journal of Economic Studies, 38(5). DOI: http://dx.doi.org/10.1108/01443581111161841.

Oulasvirta, L. (1997). Real and Perceived Effects of Changing the Grant System from Specific to General Grants. Public Choice, 91(3/4). DOI: 10.1023/A: 1004987824891 .

Owsiak, S. (2002). Podstawy nauki finansów. Warsaw: PWE.

Palley, T. (2009). Imports and the Income-expenditure Model: Implications for Fiscal Policy and Recession Fighting. Journal of Post Keynesian Economics, 32(2). DOI: http://dx.doi.org/10.2753/PKE0160-3477320211.

Pietrzak, B., Polański, Z., \& Woźniak, B. (Ed.) (2008). System finansowy w Polsce. Warsaw: Wydawnictwo Naukowe PWN.

Schuknecht, L. (2000). Fiscal Policy Cycles and Public Expenditure in Developing Contries. Public Choice, 102(1-2). DOI: 10.1023/A:1005026806998.

Sekuła, A. (2009a). Struktura subwencji wybranych powiatów ziemskich województwa pomorskiego - analiza porównawcza z lat 2005-2007. Zeszyty Naukowe. Uniwersytet Szczeciński, 530. DOI: 10.13140/2.1.5005.9044.

Sekuła, A. (2009b). System of Specific Grants for Local Government Units in Poland. In M. Buček, R. Capello, O. Hudec \& P. Nijkamp (Eds.). 3rd Central European Conference in Regional Science. Košice: Technical University of Košice. DOI: $\underline{10.13140 / 2.1 .1557 .5842 .}$. 


\section{Alicja Sekuła, Joanna Śmiechowicz}

Sekuła, A. (2010). Klasyfikacja polskich wschodnich i zachodnich obszarów przygranicznych na szczeblu NUTS 3 według poziomu rozwoju. Zeszyty Naukowe nr Uniwersytet Szczeciński, 620 DOI: 10.13140/2.1.1074.2562.

Sekuła, A. (2011). Polityka podatkowa Gdańska. Zeszyty Naukowe Wydziatowe "Studia Ekonomiczne" Uniwersytet Ekonomiczny w Katowicach, 80. DOI: 10.13140/2.1.4481.8246.

Śmiechowicz, J. (2008). Samorząd terytorialny we Francji - organizacja, zadania i finanse. Zeszyty Naukowe. Uniwersytet Szczeciński, 500. DOI: 10.13140/2.1. 3863.2483.

Szarowská, I. (2011). The Cyclicality and Development of Government Expenditure in the Visegrad Group. Scientific Papers of the University of Pardubice. Series $D, 16(21)$.

Wierzbicka, W. (2014). Potencjał innowacyjny polskich regionów - analiza taksonomiczna. Prace Naukowe Uniwersytetu Ekonomicznego we Wrocławiu. 331. DOI: $\underline{10.15611 / \mathrm{pn} .2014 .331 .23}$. 